\title{
Prospects and Problems of Digitalization of the Labor Market in Russia
}

\author{
Digilina O.B. ${ }^{1}$ Teslenko I.B. ${ }^{2}$ Abdullaev N.V., ${ }^{2}$
}

\author{
${ }^{1}$ RUDN-University, Moscow, Russia \\ ${ }^{2}$ Vladimir state University named after A. G. and N. G. Stoletov, Vladimir, Russia \\ *Corresponding author. E-mail: nizamka33@mail.ru
}

\begin{abstract}
In the article, the authors set a goal to analyze the prospects and problems of digitalization of the Russian labor market. The authors emphasize that digital technologies completely change not only production processes and the economic life of a person, but completely change the structure of the labor market and forms of employment. The authors attribute new requirements to the labor market to employees (priority in teamwork), the spread of "uber-models" of hiring to solve a specific problem, the priority of remote work (distance employment), the predominance of temporary (project) employment, the emergence of a new philosophy of workers. The authors note that the transformation of production should take place simultaneously with the training and retraining of personnel. This will require significant investment in education, the organization of cooperation between universities and enterprises, the adaptation of people to the realities of a digital society.
\end{abstract}

Keywords: digital economy, labor market, digital education, digitization of professions, information

infrastructure

\section{INTRODUCTION}

Recent years have been marked by the rapid introduction of information technology into the economy. Technologies such as wireless; industrial internet; artificial Intelligence; components of robotics and sensorics; quantum technologies; distributed registry systems; virtual and augmented reality technologies transform the business and transform the lifestyle and activities of people.

Mobile Internet and the widespread use of smartphones allows us to create a new model of counterparty interaction using platform technologies. This has a serious impact on an existing business, forcing it to transform or close. It is digitalization that currently defines a new development paradigm in the economy.

Digitalization, as a global trend of the 21 st century, radically changes the situation not only in industry markets, but also in factor markets. The labor market is no exception. Changes in real business naturally affect employment.

\section{MATERIALS AND METHODS}

The object of the study of this work is a set of changes associated with the new realities of the Russian labor market in the context of digitalization, which determine its further changes.
The authors studied regulatory documents, state federal and subfederal programs aimed at stimulating the development of digital technologies and supporting the Russian labor market, identified emerging problems and institutional traps associated with its digitalization.

Based on the material studied, the main results of the study were formulated and directions for their practical application were proposed.

\section{DISCUSSIONS AND RESULTS}

The formation of "industry 4.0", based on the use of cyberphysical systems, gives a number of significant advantages to enterprises compared with hiring workers: costs are reduced, the speed of the production program, productivity is increased, and the quality of products and services is improved. Under such conditions, it becomes natural to replace workers with automatic machines and robots, which leads to an increase in technological unemployment.

Foreign scientists believe that the effect of technological unemployment in connection with the widespread transition of production to automation will be subject to middle-skilled workers due to economic feasibility, as specialists with this level of education are quite highly paid [1]. 
This can not leave anyone indifferent, since, according to available information, at the beginning of 2019, 7 billion people lived in the world, of which about 3.5 billion were able-bodied people over 15 years old, and jobs existed only for 1.2 billion. Given the rollout of digital transformation, the unemployment problem is compounded, significant changes are taking place in the labor market, and both the government and private companies and workers themselves will have to adapt to survive [2].

Researchers have noted that new trends caused by digitalization have appeared and are developing in the labor market. These include:

1. Demand for hybrid skills. If a few years ago, employers and HR managers focused on the so-called soft skills (flexible, general managerial skills - teamwork, communication skills, responsibility, self-discipline, leadership, creativity, etc.) when selecting and hiring employees, then now, employers have again begun to attach great importance to hard skills (professional skills and competencies), without refusing to recognize the importance of soft skills. Therefore, employees with hybrid skills, which combine both soft skills and hard skills, are of particular value now. According to a study by Burning Glass Technologies, a quarter of a billion vacancies in 250 professions involve hybrid skills, half of which are related to digital competencies [3].

2. Digitization of professions. Employees of the "old" professions are beginning to widely use digital technologies various kinds of mobile applications. At the same time, the professions themselves do not disappear, because many of them require a living worker and personal communication with him.

3. The role of systemic strategic and creative thinking is growing. Robots copes well with routine, monotonous, heavy, harmful work, such activities where high speed information processing is required.

But the possibilities of artificial intelligence are not unlimited, because the algorithm of the robot is set by a person. Therefore, the robot cannot solve creative problems by itself, it does not have empathy.

4. The design approach. The traditional organizational structure of company management is replaced by design. Project teams are temporary; they are formed for a specific business task; the composition of teams often changes, a person, depending on skills, can be a leader in one project and a simple member of a team in another. A vertical career within one organization is no longer so significant. For employees, horizontal movement, both within the company and between companies, is more interesting. Among specialists, employment on demand begins to spread more and more. The better a skill is mastered, the higher the employee's chance of being invited to a new project. In order to be aware of such employees, the assessment of their skills must be transparent, and the results measured.

5. The volume of remote work is growing. This leads to the disappearance of the territorial and organizational ties of the employee to the employer. Research data shows that employees work more productively outside the office, working with freelancers stabilizes the business, as staff turnover disappears. According to researchers, in a ten-year perspective, $75 \%$ of companies will work with freelancers. 6. Distribution of "uber-models" of hiring to solve a specific problem, where the IT platform plays the role of an intermediary between the employee and the employer. Already, this model is used in taxi services, delivery, telemedicine, educational services, etc. Overseas, digital platforms have already been created for a long time to register job seekers. In Russia, there are also such services Expert Me, LegalSpace, HR-sreda [3].

7. The appearance on the labor market of a new type of worker. These are millennial workers. These, or, in other words, generation $\mathrm{Y}$, include all people born between the beginning of the $80 \mathrm{~s}$ and the end of the $90 \mathrm{~s}$ of the XX century. These are those who are now from 18 to 35 years old. According to research, the peculiarities of these workers include a peculiar understanding of success (this is not status, prestigious work, career and wealth, but the diversity of life), resistance to coercion; short horizon of life planning; lack of reverence for elders; perception of oneself as a unique and talented person [4]. These employers have to reckon with.

Modern labor market trends are fraught with both advantages and disadvantages.

In particular, the expansion of the scope of remote work leads to such negative consequences as:

- disaggregation of companies (based on the use of outsourcing for many business processes) with their possible subsequent destruction,

- the lack of reference to the territory (for example, the work of call centers) increases the pressure of international competition on the wages of workers in other countries towards their reduction or "freezing",

- the proportion of temporary or part-time workers is increasing, and gradually such employment begins to be permanent and sustainable,

- the social situation of temporary workers is unstable: income is unstable, there are no social guarantees.

Along with these consequences, as noted above, digitalization jeopardizes the employment of workers in a number of professions, such as bank employees, accountants, auditors, supervisors, notaries, insurers, registrars, lawyers, administrative employees, civil servants, recruiters, news journalists, etc. So Sberbank has already refused the services of 450 lawyers, since the neural network is preparing claims faster and better. The Bot of the Associated Press, an international news and news agency, is already writing two thousand meaningful news per second. Not so long ago, O. Sharp and R. Goodwin presented a full-length film shot in a script written by a neural network [4].

According to the rector of the Higher School of Economics, Y. Kuzminov, in the next 20 years, 10-15 million of the currently working 70 million Russians will be forced out of the labor market. Entire sectors of the economy are at stake. According to the forecast of the Center for Monitoring Technological Modernization and Scientific and Technical Development of the ONF (All- 
Russian Popular Front), by 2027 the largest reduction in jobs will occur in manufacturing (by 23.9\%), in agriculture (by 14.8\%) and in transport industry (by $9.3 \%)$.

The transition to the digital economy will have the greatest impact on the labor markets of Moscow (according to forecasts, it will decrease by more than 670 thousand jobs), the Moscow region (will decrease by 350 thousand places), St. Petersburg (by 270 thousand places). In total, in 10 years about 6.7 million jobs will be automated. In the ten-year horizon, digitalization can provide an increase in labor productivity by $8-14 \%$ [4].

However, it should be borne in mind that the complete automation of professions is impossible, and the pace of automation cannot be swift due to the high cost of new equipment. In addition, digitalization not only changes old professions and leads to the disappearance of some of them, but also creates new ones.

Analysts at the international consulting company Boston Global Group have concluded that structural changes caused by the spread of the "numbers" will increase demand for workers with skills in the field of information and communication technologies (ICT). The most popular will be programmers, system engineers, ICT designers, robotics, consultants on the implementation of innovations, coaches on the development of intellectual abilities. The emergence of high-tech areas of activity will also require the creation of new jobs [1].

However, the proliferation of digital technology can lead to a shortage of ICT specialists. According to the forecast of Roland Berger, an international management consulting company, by 2030 in Europe alone, staff shortages will reach 50 million jobs [3]. Those. A difficult situation will arise in the labor market: an increase in technological unemployment in some sectors and a shortage of qualified personnel in others.

In such conditions, the issues of digital education, advanced training, career changes, changes in approaches to the entire education system, and so on, become priority.

In Russia, in 2017, the Digital Economy of the Russian Federation program for 2017-2030 was adopted (Decree of the Government of the Russian Federation of July 28, 2017 No. 1632-r).

One of the program areas is dedicated to personnel and education. According to him, the number of students in the field of ICT should be at least 80 thousand people in the academic year 2020/2021, and reach 120 thousand people by the academic year 2024/2025 [5].

However, it should be borne in mind that the complete automation of professions is impossible, and the pace of automation cannot be swift due to the high cost of new equipment. In addition, digitalization not only changes old professions and leads to the disappearance of some of them, but also creates new ones.

Achievement of goals will depend on the readiness of the education system and business to provide training for soughtafter specialists and improve the skills of existing ones. This will also determine the rate of adaptation of the labor market to the challenges of digitalization [6].
The transformation of production should take place simultaneously with the training and retraining of personnel. This will require significant investment in education, the organization of cooperation between universities and enterprises, the adaptation of people to the realities of a digital society. Many foreign scientists, businessmen and venture entrepreneurs believe that in conditions of forced rivalry between a person and a robot, it is necessary to increase the level of guaranteed income in order to enable a person to live with dignity and at the same time combine study with work [1].

Workers should get used to the idea that in modern conditions of rapid transformation, one should not rely on stable employment and a career in their traditional sense. The key to success is constant self-education, gaining new competencies, creativity, initiative, the desire to adapt to any changes.

The digital economy is remaking the labor market, the system of labor relations. A person will gradually master new technologies, and digital literacy will become a basic skill. Automation of production will free up time for creativity and the development of new professional qualities. For employers, hiring employees and evaluating their performance will become transparent. Labor relations will be diverse - along with the usual personal interaction, virtual models and schemes will be widely used [3].

In general, digital technologies should become a powerful tool for improving the economy and society in terms of improving the efficiency of human capital, solving social problems, creating a new quality of the national product, simplifying the interaction of the state, business and the population [1].

\section{CONCLUSION}

Summing up the general result, it should be noted that humanity is going through an epochal period of a change in the system of relations that transform the traditional foundations of society.

As for the labor market, digitalization stimulates technological unemployment: machines and robots replace people in production. According to the World Economic Forum (WEF), in the near future robots will destroy more than 75 million jobs in the world, although they will also create 133 million new ones [7]. Jobs will arise in high-tech industries, increasing demand for new professions and high qualifications.

Workers are moving from the primary and secondary sectors of the economy to the tertiary and quaternary, and market conditions are changing.

The requirements for professional knowledge, skills, abilities and skills are increasing. Labor is becoming more creative, intellectual.

Employment models are transforming. Remote interaction technologies are gaining more and more popularity, reducing employee turnover and saving employer costs.

The employee himself is also changing in terms of abandoning old stereotypes regarding employment, career 
and status. Young workers value freedom, independence, creativity and self-organization without pressure from the employer.

All this enhances the role of the education, training and retraining system, and makes it necessary to switch to lifelong learning throughout life.

So, the impact of digitalization on the labor market is mixed. But the transition to the "figure" is inevitable, therefore, the task of the state and business is to provide conditions for mitigating its negative consequences for the labor market

\section{REFERENCES}

[1] E.S. Borisova, A.V. Komarov, The modern labor market in the conditions of formation and development of the digital economy // Journal of Science. Society. Defense. (noo-journal.ru) / 2019.No 3 (20). [Electronic resource]. - Access mode: https://www.noo-journal.ru/nauka-obshestvo-oborona/201 9-3-20/article-0197-1/

[2] How the digital transformation will change the labor market in Russia. [Electronic resource]. - Access mode: $\quad$ https://yandex.ru/turbo?text=https $\% 3 \mathrm{~A} \% 2 \mathrm{~F}$ $\% 2$ Fwww.forbes.ru\%2Fkarera-i-svoy-biznes \%2F371537kak-cifrovaya-transformaciya-izmenit-rynok-truda- vrossii January 24, 2019

[3] Work of the future: how the labor market will change in the digital age. [Electronic resource]. - Access mode: https://sobesednik.ru/tehnologii/20191108-rabota- budushego-kak-izmenitsya-rynok-truda-v-cifrovuyuepohu

[4] Genkin A.S. Paradoxes and transformation: the labor market in the digital economy. [Electronic resource]. - Access mode: https://narfu.ru/upload/medialibrary/928/Genkin-A.-S.Paradoksy-i-transformatsiya-rynok-truda-v-tsifrovoyekonomike.pdf

[5] Government of the Russian Federation. Order of July 28, 2017 No. 1632-r. Program "Digital Economy of the Russian Federation". [Electronic resource]. - Access mode:

http://static.government.ru/media/files/9gFM4FHj4PsB79 I5v7yLVuPgu4bvR7M0.pdf

[6] Shvets D.D. The problem of employment of the Russian labor market in the context of the digitalization of the economy. Journal of Economic Research and Development. [Electronic resource]. - Access mode: http://edrj.ru/article/16-06-2019 Journal of Economic Research and Development

[7] WEF: In four years, technology will destroy 75 million jobs. But they will create 133 million new ones. Abstract of the large-scale report of the World Economic Forum on the future of the labor market. [Electronic resource]. - Access mode: https://www.cossa.ru/news/221773/ 